\title{
Overview of Brazilian Scientific Production in Psychological Evaluation
}

\author{
Ariállisson Monteiro dos Santos - Universidade Federal de Mato Grosso do Sul, Campo Grande, Brasil \\ Alexandra Ayach Anache - Universidade Federal de Mato Grosso do Sul, Campo Grande, Brasil \\ Ronilce Cavichioli de Santana - Universidade Federal de Mato Grosso do Sul, Campo Grande, Brasil
}

\begin{abstract}
Attentive to the scenario of the Psychological Assessment, this study aimed at the meta-scientific investigation of national publications dated from 2003-2012. 696 articles obtained through Index Psi, PEPSIC, LILACS, and SciELO were analyzed under the following categories: disclosure, authorship, speech, theme and methodology. Among the results we met: a) an increase in the domestic production from 2003 to 2008 and its subsequent slowdown in publications; b) the high concentration of production in the Southeastern region of the country; c) the predominance of empirical studies for the development of instruments; d) the focus in the fields of Clinical Psychology, Health Psychology, and School Psychology; e) absence of work that expose the articulation and integration of data in the evaluation process. Therefore, we discuss the need for investment in underdeveloped regions in this area of production, approach diversification, themes and contexts, and attention to the effective capability of methods integration in Psychological Assessment.

Keywords: psychological assessment, psychometrics, meta-analysis
\end{abstract}

\section{Panorama da Produção Científica Brasileira em Avaliação Psicológica}

\begin{abstract}
Resumo
Atento ao cenário da Avaliação Psicológica, este trabalho objetivou a investigação metacientífica das publicações nacionais do período de 2003 a 2012. Foram analisados 696 artigos obtidos por meio das indexadoras Index-Psi, PEPSIC, LILACS e Scielo, nas categorias de divulgação, autoria, discurso, temática e metodologia. Entre os resultados encontrou-se: a) o aumento da produção nacional de 2003 a 2008 e sua subsequente desaceleração nas publicações; b) a alta concentração de produção no sudeste do país; c) a predominância dos estudos empíricos para o desenvolvimento de instrumentos; d) o foco nos campos da Psicologia Clínica, Psicologia da Saúde e Psicologia Escolar; e e) a ausência de trabalhos que exponham a articulação e integração de dados no processo avaliativo. Com isso, discute-se a necessidade de investimento, nas regiões pouco desenvolvidas, na produção dessa área, diversificação de abordagem, temas e contextos, e atenção à efetiva capacidade de integração de métodos na Avaliação Psicológica.

Palavras-chave: avaliação psicológica, psicometria, meta-análise
\end{abstract}

Panorama de la Producción Científica Brasileña en Evaluación Psicológica

\begin{abstract}
Resumen
Considerando el panorama de la Evaluación Psicológica, este estudio tuvo como objetivo la investigación meta-científica de las publicaciones nacionales entre los años 2003 y 2012. Fueron analizados 696 artículos obtenidos por medio de los indizadores Index Psi, PEPSIC, LILACS y SCIELO, en las categorías de divulgación, autoría, discurso, temática y metodología. En los resultados se verificó: a) aumento de la producción nacional de 2003 a 2008 y en consecuencia la desaceleración de publicaciones b) alta concentración de la producción en el sudeste del país; c) predominio de los estudios empíricos para el desarrollo de instrumentos; d) enfoque en el campo de la Psicología Clínica, Psicología de la Salud y Psicología Escolar; y e) ausencia de trabajos que exponen la articulación e integración de los datos en el proceso evaluativo. Con este resultado, se discute la necesidad de inversiones en las regiones poco desarrolladas en la producción de esta área, diversos abordajes, temas y contexto y atención a la efectiva capacidad de integración de métodos en Evaluación Psicológica.

Palabras clave: evaluación psicológica, psicometría, meta-análisis
\end{abstract}

\section{Introduction}

From 1990 to early in 2000, the Federal Council of Psychology (CFP), with the support of the Forum of National Entities of the Brazilian Psychology (FENPB), especially members of the National Association for Research and Graduate Studies in Psychology (ANPEPP), the Brazilian Institute of Psychological Assessment (IBAP), and the Brazilian Society of Rorschach and other Projective Techniques (SBRo), was involved in a wide-ranging discussion of training and technical and scientific development in Psychological Assessment (CFP, 2004). With the works that bring us the history of psychological assessment in Brazil (Alchieri \& Cruz, 2003; Chiodi \& Wechsler, 2008; Noronha \& Reppold, 2010; Noronha \& Alchieri, 2005; Pasquali \& Alchieri, 2001), we can see that serious issues, such as deficiencies in the training process, lack of studies for the development of psychological instruments and the indiscriminate use of instruments without 
psychometric research in the Brazilian context, made these ethical actions emergent to ensure quality and technique in a professional practice.

By joint efforts, important productions arose in that period. The manifesto of the Working Group on Psychological Assessment (Noronha et al., 2002), and the translation of The ITC Guidelines on Test Use (International Testing Commission, 2003) into Brazilian Portuguese, are some of the examples, mentioned by Noronha and Reppold (2010), that brought to attention the need to improve the training of psychologists in this area. Among other things, the recommendations noted the pertinence of development of critical and analytical skills of psychologists for the use of psychological tests and for the interpretation of the data from the assessment process.

In turn, the CFP also developed resolutions designed to address the issue (CFP, 2000; 2002a; 2002b; 2003b). With a highlight to the year 2001 when the first regulation on the development, marketing and use of psychological assessment tools in the country was created (CFP, 2001), which was improved in Resolution No. 002/2003, with the establishment of the Advisory Committee on Psychological Assessment (CFP 2003a). One of the focuses of this measure was to condition the use of psychological instruments to the presentation of satisfactory studies for its reasoning, accuracy, validity and standardization in order to safeguard the quality of psychological assessment practices, restricted to the professional psychologist with art. 13 of Law No. 4.119, from 1962.

We consider, like Anache and Corrêa (2010), that the CFP's effort to guarantee theoretical and methodological rigor applied to Psychological Assessment has strengthened the discussion forums and publications dedicated to the development and improvement of the area in Brazil. In addition, the ethical and technical principles of the professional practice invited the scientific community to examine and position itself on the potential and validity of techniques of Psychological Assessment, within Psychology perspectives and performance contexts.

It should be noted that these entities pushed for changes in the national scenery, and its results, concentrated in the early 2000s, aimed to influence the practice and the teaching and research, drawing attention to the theoretical and empirical investigations that should be promoted in the area. Having those in sight, a metascientific work was produced (Witter, 1999) with the analysis of the Brazilian production of articles in
Psychological Assessment in the period from 2003 to 2012, which corresponds to the first decade since the establishment of the Consultative Committee in Psychology Assessment. The metascientific research has already been explored within psychology (Barroso, 2010; Cunha, Suehiro, Oliveira, Pacanaro, \& Santos, 2009; Joly, Berberian, Andrade, \& Teixeira, 2010; Suehiro, Rueda, Oliveira, \& Pacanaro, 2009, Suehiro, Rueda, Oliveira, \& Pacanaro, 2009; Suehiro, Cunha, \& Santos, 2007; Suehiro \& Rueda, 2009), and with it we aim to provide data on distribution of the national scientific production, in order to identify the direction the Psychological Assessment has been taking, and also the gaps that remain.

\section{Method and Procedure}

For analysis of the Brazilian production in Psychological Assessment, the indexations of scientific articles available were consulted in four databases linked to the Portal BVS-Psi ULAPSI Brazil, as follows: Index-Psi, PEPSIC, LILACS and SciELO. The surveys were conducted in March 2013 and afterwards in February 2014, using, separately, the descriptors 'psychological assessment' and 'psychological tests' in Portuguese.

With this procedure were identified 1,048 papers published in the years 2003 to 2012. For initial verification of these studies, we used a skimming reading technique, and therefore a focused search on the information required for the identification and methodology presented in the authors' approach (Marconi \& Lakatos, 2010). As a result, 334 of the materials were excluded because there was no sign of a relationship with the subject of psychological assessment. Were kept all articles in which psychological assessment (a) constituted the main theme of the study, either by addressing tools, techniques, methods, constructs, training, ethical, technical or historical aspects; or (b) secondly, was employed as part of the methodology of an empirical investigation, with a relevant space in the theoretical discussion.

By criterion were also excluded the publications that were uniquely foreign $(N=48)$, which did not consist in a theoretical, empirical study or literature review $(N=$ $22)$, and did not provide access to the full content ( $N$ =36). The corpus of analysis, reduced to 608 scientific articles, was registered for consideration in the disclosure by database category. As a complement, were included 88 articles coming from a search of the 'psychological assessment' and 'psychological tests' terms in Google Scholar. In the search engine were analyzed the first 500 
results presented in order of relevance, with selection of productions that fit the previously established criteria and were linked to the same databases used.

The whole process of composing the analysis corpus $(N=696)$ is illustrated in Figure 1.

The analysis of the materials was made using items drawn based on the categories of Witter (1999), including disclosure, authorship, discourse, subject and methodology. From disclosure, we analyzed the concentration of articles according to databases, journals and year of publication. Considering authorship, institutional affiliation and region of origin were examined. In discourse, the type of study was identified - theoretical, empirical or literature review - and the theme, the context of implementation of the study, was discriminated. Finally, the methodology tools used in the research were identified.

All publications were examined in full, to allow confirmation of the analysis and other relevant considerations. In addition, for rigor, we adopted a dual evaluation of the items application contexts and instruments used.

\section{Results}

\section{Disclosure}

According to data from the National Council for Scientific and Technological Development (CNPq, n.d.), in Humanities, $85.9 \%$ of the scientific publications produced in Brazil by $\mathrm{PhD}$ researchers in the period 2003-2010 were distributed in journals of national circulation. Based on this information, IndexPsi, PEPSIC, LILACS and SciELO were the indexations selected, for their prominence in the Brazilian literature. Out of the research conducted in the databases, 608 materials composed the sample of analyzed publications, and it becomes possible to see exclusive titles, and common titles to more than one source, as is expressed in Figure 2.

As shown, the four databases seem to be complementary for the expansion of the researched literature, and they produce different gathering potential on the matter. The low or high expansion of the volume of results, as a combination of two or more search sources, is directly influenced by existing differentiation in indexing between them. Thus, it appears that Index-Psi and LILACS, between them, were those of greater differentiation in content related to psychological assessment. In addition, as Barroso (2010) pointed out, we have also found that articles indexed to Scielo were often not displayed as a result in its platform.

In reviewing publications by year, as shown in Figure 3, one can see a progressive increase in the number of national publications in psychological assessment between 2003 and 2008. The peak in

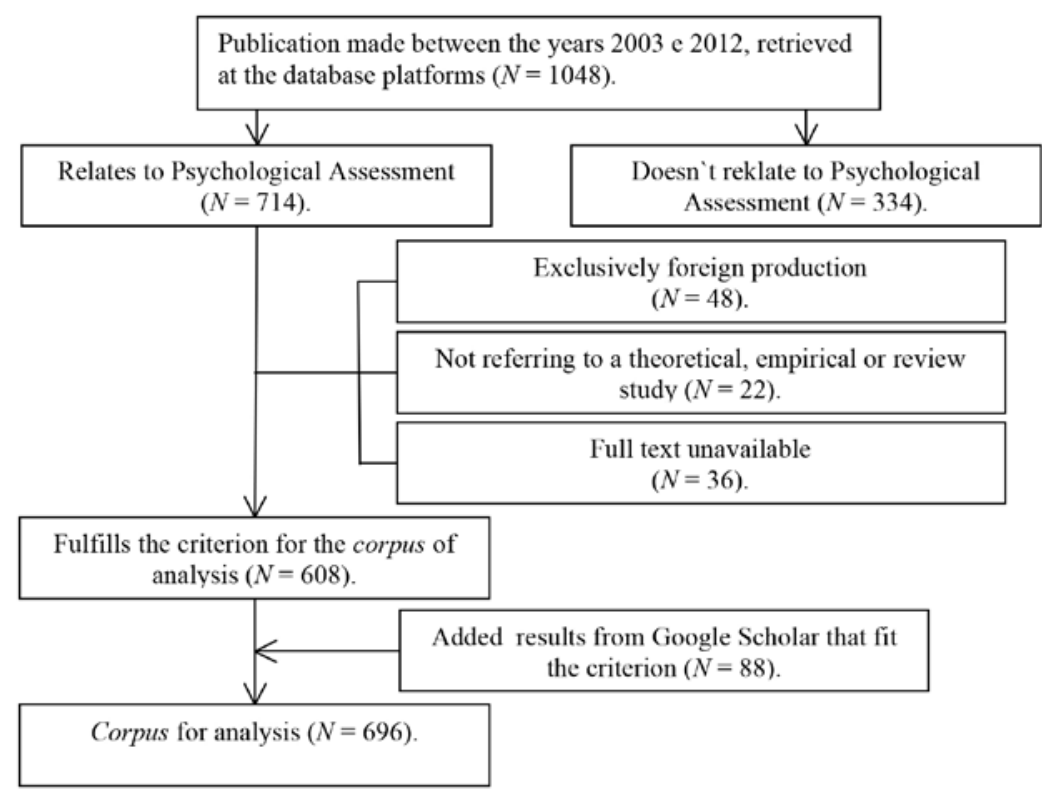

Figure 1. Process of building the corpus of analysis. 
this amount of publications occurred in 2008, after which a deceleration is perceivable. The average of publications was 69.60 articles per year, on a standard deviation of 19.65 .

Figure 3 also provides an opportunity to verify aspects on the studies subject, out of 696 articles, a total of 303 publications, or $43.53 \%$, had the specific purpose of construction, standardization and validation of an instrument or psychological construct. The prevalence of development studies of psychological assessment instruments is representative in all the years considered, present in more than $50 \%$ of the research presented in 2010 and the tending to an average of $43.54 \%(N=30)$ of publications per year with a standard deviation of 5.98. A significant amount of the proposed studies within the area.

On all items it was possible to identify the research journal where the researches were published,

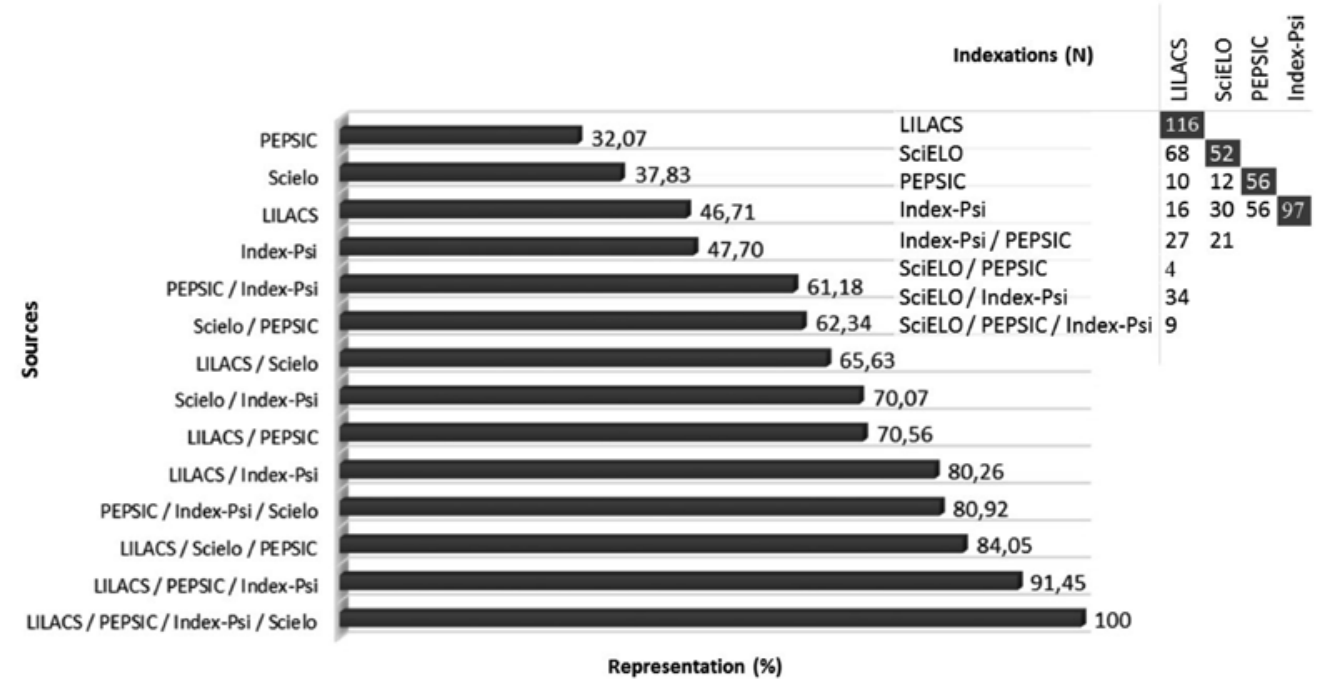

Figure 2. Publications identified according to an isolated or combined analysis of indicators.

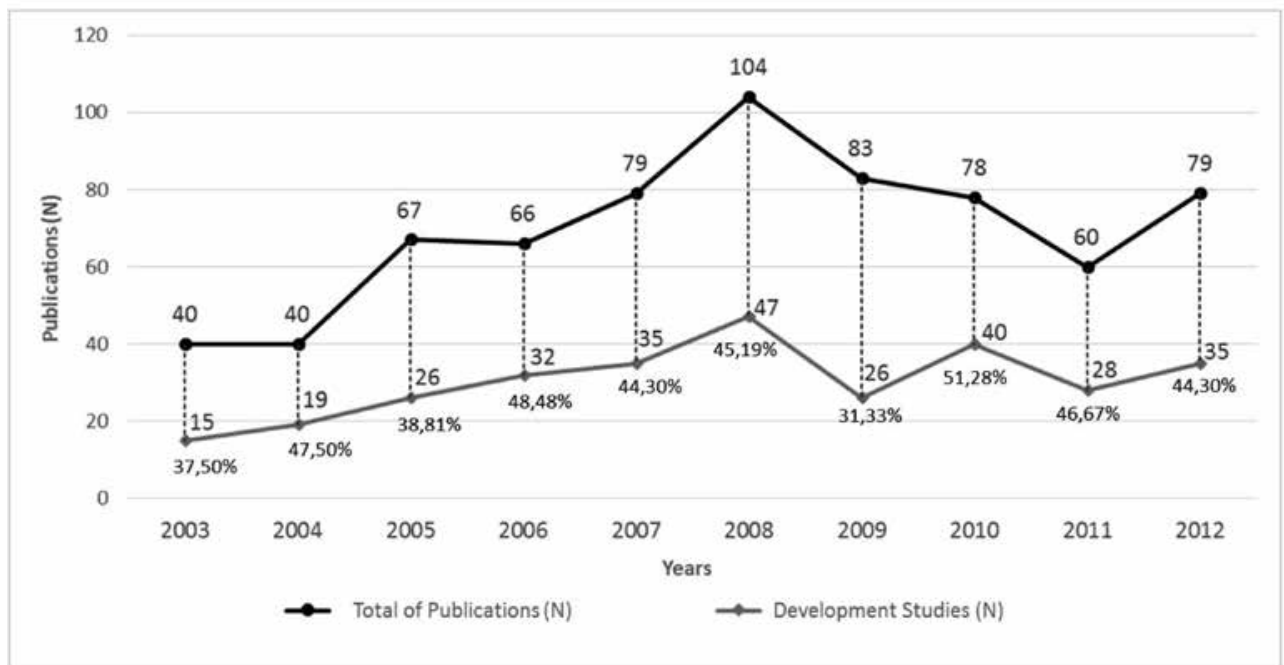

Figure 3. Distribution of the publications per year, highlighting the studies with development of psychological instruments.

Note. The percentage shows the annual volume of studies with the development of psychological instruments. 
constituting 98 vehicles. Table 1 shows those with four or more publications captured by the study $(N=29)$.

The ten most widely disclosed periodics detained more than half of the collected publications (61.63\%). Of these, those of greatest expression were: Avaliação Psicológica, from the Brazilian Institute of

Table 1

Periodics with Highest Volume of Publications in Psychological Assessment in the | Years 2003-2012

\begin{tabular}{lcc}
\hline \multirow{2}{*}{ Periodic of publication } & \multicolumn{2}{c}{ Articles } \\
\cline { 2 - 3 } & $(\mathrm{N})$ & $(\%)$ \\
\hline Aval. Psicol. & 145 & 20.83 \\
Psico-USF & 53 & 7.61 \\
Psicol. Reflex. Crit. & 42 & 6.03 \\
Psic. (Vetor) & 39 & 5.60 \\
Rev. Bras. Psiquiatr. & 30 & 4.31 \\
Estud. Psicol. (Campinas) & 28 & 4.02 \\
Psicol. Teor. Prat. & 27 & 3.88 \\
Psicol. Cienc. Prof. & 20 & 2.87 \\
Paidéia (Ribeirão Preto) & 17 & 2.44 \\
Bol. Psicol. & 15 & 2.16 \\
Rev. Bras. Orientac. Prof. & 15 & 2.16 \\
Interação Psicol. & 14 & 2.01 \\
Psicol. Estud. & 14 & 2.01 \\
Psic.: Teor. e Pesq. & 13 & 1.87 \\
Aletheia & 12 & 1.72 \\
Psico (Porto Alegre) & 12 & 1.72 \\
Psicol. Esc. Educ. & 12 & 1.72 \\
Arq. Neuro-Psiquiatr. & 11 & 1.58 \\
Rev. Saúde Pública & 10 & 1.44 \\
Estud. psicol. (Natal) & 9 & 1.29 \\
Psicol. Argum. & 9 & 1.29 \\
Estud. pesqui. psicol. & 8 & 1.15 \\
Fractal, Rev. Psicol. & 7 & 1.01 \\
Psicol. Pesq. & 7 & 1.01 \\
Cad. Saúde Pública & 6 & 0.86 \\
Interam. J. Psychol. & 5 & 0.72 \\
Rev. Bras. Educ. Espec. & 5 & 0.72 \\
Arq. Bras. Psicol. & 4 & 0.57 \\
J. Bras. Psiquiatr. & 4 & 0.57 \\
\hline & & \\
\hline & &
\end{tabular}

Note. Beside these, there were another 42 periodics with a single publication, 20 with two and 7 with 3 publications.
Psychological Assessment; Psico-USF published by Universidade de São Francisco organized by the Stricto Sensu Psychology post-graduation team; Psicologia Reflexão e Crítica, from the Psychology Post-Graduationdo School of Universidade Federal do Rio Grande do Sul; Psic. from Vetor Editora; and Revista Brasileira de Psiquiatria organized by the Brazilian Psychiatric Association (ABP).

\section{Authorship}

The authorship analysis focused on identifying regional and institutional distribution of the researches in psychological assessment. These concentrations, based on the institutional ties of the authors, are presented in Table 2 and followed by additional data.

The data enables an isolated reading of the percentage of publications by region of the country, in which are considered the authorship and co-authorships in publications. Since in 35 of the publications there is the simultaneous presence of researchers from the South and Southeast, it seems that $90.94 \%$ of the country's production has the presence of one or more researchers from these regions. In turn, if the proportion of research, produced exclusively by researchers from a single region, is analyzed, it is calculated that these productions total $87.02 \%$ in the Southeast, $68.42 \%$ in the South, $60.47 \%$ in the Midwest, $60 \%$ in the North, and $54.24 \%$ in the Northeast.

Of the 696 publications in only $4(0.57 \%)$ it was not possible to verify the affiliation of authors to an institution, and in all 208 different institutions were identified. Of these, 101 institutions are in the Southeast, 36 are from the South, 19 in the Northeast Region, 10 in the Midwest Region, 4 in the Northern Region, and 38 are foreign institutions.

Among the authors were also identified professionals that were linked to public and private research and development institutions $(N=8)$, government agencies $(N=8)$, specialized publishers $(N=2)$, clinics and care centers $(N=6)$, hospitals $(N=3)$, foundations to support the development of research $(N=2)$, and professional societies $(N=1)$. But in only $8.61 \%$ of the publications $(N=18)$, the lead author came from these institutions.

\section{Speech and Focus}

With regard to the types of study, we found empirical research publications - 79.5\% $(N=553)$, literature reviews - $11.6 \%(N=81)$ and the remaining $8.9 \%(N=62)$ were theoretical. It is noted that, 
Table 2

Institutions with the Highest Volume of Publications in the Area of Psychological Assessment, according to their Region

\begin{tabular}{|c|c|c|c|}
\hline \multirow{3}{*}{ Region or institution } & \multirow{3}{*}{$(\mathrm{N})$} & \multicolumn{2}{|c|}{ Representation } \\
\hline & & Regional & National \\
\hline & & \multicolumn{2}{|c|}{$(\%)(\%)$} \\
\hline Southeastern Region & 516 & 100 & 74.14 \\
\hline Universidade São Francisco (USF) & 235 & 33.15 & $21 ., 60$ \\
\hline Universidade de São Paulo (USP) & 107 & 15.09 & 9.83 \\
\hline Pontifícia Universidade Católica de Campinas (PUC-Campinas) & 32 & 4.51 & 2.94 \\
\hline Universidade Federal de Minas Gerais (UFMG) & 27 & 3.81 & 2.48 \\
\hline Universidade Estadual de Campinas (Unicamp) & 25 & 3.53 & 2.30 \\
\hline Universidade Presbiteriana Mackenzie & 23 & 3.24 & 2.11 \\
\hline Universidade Federal de São Paulo (UNIFESP) & 22 & 3.10 & 2.02 \\
\hline Universidade Estadual Paulista (UNESP) & 18 & 2.54 & 1.65 \\
\hline Universidade Federal do Rio de Janeiro (UFRJ) & 15 & 2.12 & 1.38 \\
\hline Universidade do Estado do Rio de Janeiro (UERJ) & 10 & 1.41 & 0.92 \\
\hline Universidade Federal de São Carlos (UFSCar) & 10 & 1.41 & 0.92 \\
\hline Universidade Federal de Uberlândia (UFU) & 10 & 1.41 & 0.92 \\
\hline Pontifícia Universidade Católica de São Paulo (PUC-São Paulo) & 9 & 1.27 & 0.83 \\
\hline Universidade Federal do Espírito Santo (UFES) & 9 & 1.27 & 0.83 \\
\hline Southern Region & 152 & 100 & 21.84 \\
\hline Universidade Federal do Rio Grande do Sul (UFRGS) & 89 & 41.78 & 8.18 \\
\hline Pontifícia Universidade Católica do Rio Grande do Sul (PUC-RS) & 31 & 14.55 & 2.85 \\
\hline Universidade Federal de Santa Catarina (UFSC) & 10 & 4.69 & 0.92 \\
\hline Universidade do Vale do Rio dos Sinos (Unisinos) & 9 & 4.23 & 0.83 \\
\hline Universidade Luterana do Brasil (ULBRA) & 7 & 3.29 & 0.64 \\
\hline Universidade Federal de Santa Maria (UFSM) & 6 & 2.82 & 0.55 \\
\hline Universidade de Santa Cruz do Sul (UNISC) & 5 & 2.35 & 0.46 \\
\hline Universidade Estadual de Maringá (UEM) & 5 & 2.35 & 0.46 \\
\hline Universidade Federal de Ciências da Saúde de Porto Alegre (UFCSPA) & 5 & 2.35 & 0.46 \\
\hline Universidade Federal do Paraná (UFPR) & 5 & 2.35 & 0.46 \\
\hline Northeastern Region & 59 & 100 & 8.48 \\
\hline Universidade Federal do Rio Grande do Norte (UFRN) & 15 & 25.00 & 1.38 \\
\hline Universidade Federal da Paraíba (UFPB) & 10 & 16.67 & 0.92 \\
\hline Universidade Federal do Recôncavo da Bahia (UFRB) & 6 & 10.00 & 0.55 \\
\hline Universidade Tiradentes (Unit) & 6 & 10.00 & 0.55 \\
\hline Universidade Federal do Ceará (UFC) & 4 & 6.67 & 0.37 \\
\hline Universidade Federal de Pernambuco (UFPE) & 3 & 5.00 & 0.28 \\
\hline Midwest Region & 43 & 100 & 6.18 \\
\hline Universidade de Brasília (UnB) & 30 & 58.82 & 2.76 \\
\hline Pontifícia Universidade Católica de Goiás (PUC-Goiás) & 8 & 15.69 & 0.74 \\
\hline Universidade Católica de Brasília (UCB) & 4 & 7.84 & 0.37 \\
\hline Centro Universitário de Brasília (UniCEUB) & 3 & 5.88 & 0.28 \\
\hline Northern Region & 5 & 100 & 0.72 \\
\hline Universidade Federal do Amazonas (UFAM) & 3 & 50 & 0,28 \\
\hline
\end{tabular}

Note. Also $5.98 \%(N=41)$ of the Works had co-authorship with a foreign researcher. 
except in the case of the psychometric qualities, there is no emphasis on discussion or reviewing weaknesses and limitations of psychological tests, and there is no emphasis on the clinical judgment involved in the process of planning, handling and interpretation of the assessment results. In interpreting we still observed the convenience of approaching isolated data, not relating to the history of the subject, context or other relevant factors.

On the topic and context to which the studies apply, two categories of our own were established, and another ten taken as reference to the categories of the Psychological Test Evaluation System (SATEPSI). Two independent evaluators, who took in consideration in their evaluation that the same study can apply to more than one context or subject, conducted the analysis. The result is listed in Table 3 .

Followed by hospital and health psychology, and school and education psychology, work linked to the clinical context stand out from the application contexts of the studies in Psychological Assessment. Inversely, smaller expressions are among the sports psychology contexts and community psychology.

\section{Methodology}

It was found that $82.04 \%$ of the considered studies $(n=571)$ had employed or approached determined psychological assessment instrument. Once the frequency was analyzed, of each instrument in the research, it appears that most of them have a low occurrence in the studies included in the years 2003 2012. Namely, 297 (68.27\%) instruments appeared in only one publication, and other $89(20.45 \%)$ were used on no more than two or three studies listed. Disregarding those without a name $(N=41), 435$ instruments are identified, which consist of psychological instruments, developing instruments, and screenings, also called testing devices, that are shared for use in many areas. In the analysis, we can see that fifty instruments were frequent in 4 or more researches, and these are shown in Table 4.

It is observed, as shown in Table 4 that the Beck scales were the most frequently instruments in the studies. It`s important to highlight though, that these consist of four instruments often used separately, which expands the possibilities of use. In this framework, the instruments were analyzed with distinction of their

Table 3

Themes and Context of the Studies

\begin{tabular}{lcc}
\hline \multirow{2}{*}{ Categories } & \multicolumn{2}{c}{ Publications } \\
\cline { 2 - 3 } Training, education and practice & $(\mathrm{N})$ & $(\%)$ \\
General theme in psychological assessment & 17 & 2,4 \\
Clinical psychology & 38 & 5,5 \\
Psychology of health/hospital & 240 & 34,5 \\
School and educational psychology & 184 & 26,4 \\
Psychology of work and organizations & 124 & 17,8 \\
Neuropsychology & 67 & 9,6 \\
Vocational guidance and counseling & 62 & 8,9 \\
Forensic psychology/legal & 51 & 7,3 \\
Traffic psychology & 39 & 5,6 \\
Community psychology & 25 & 3,6 \\
Sport psychology & 17 & 2,4 \\
Undefined as to the context & 3 & 0,4 \\
Total publications & 71 & 10,2 \\
\hline
\end{tabular}

Note. Were also added to the undefined categories those that applied to 4 or more different contexts. 
Table 4

Instruments with a Highest Occurrence in Researches in the Corpus of Analysis

\begin{tabular}{|c|c|c|}
\hline \multirow{2}{*}{ Instrument ${ }^{*}$} & \multicolumn{2}{|c|}{ Occurrence } \\
\hline & $(\mathrm{N})$ & $(\%)$ \\
\hline Beck Scales & 38 & 5.46 \\
\hline Reasoning Battery Tests (BPR-5) & 16 & 2.30 \\
\hline Pfister Colored Pyramids Test & 15 & 2.16 \\
\hline Professional Counseling Scale (EAP) & 14 & 2.01 \\
\hline Wechsler Intelligence Scale for Children (WISC III) & 14 & 2.01 \\
\hline Raven`s Coloured Progressive Matrices - Special Scale (CPM) & 12 & 1.72 \\
\hline Mayer-Salovey-Caruso Emotional Intelligence Test (MSCEIT) & 10 & 1.44 \\
\hline Mini-Mental State Examination (MEEM) & 10 & 1.44 \\
\hline Bender Visual-Motor Gestalt Test - System of Gradual Puntuation (B-SPG) & 10 & 1.44 \\
\hline Child Behavior Checklist (CBCL/6-18) & 9 & 1.29 \\
\hline Childrens Depression Inventory (CDI) - Kovacs & 9 & 1.29 \\
\hline Self-Directed Search (SDS) & 9 & 1.29 \\
\hline Extraversion Factorial Scale (EFEx) & 8 & 1.15 \\
\hline Sixteen Personality Factor Questionnaire (16PF) & 8 & 1.15 \\
\hline Bender Visual-Motor Gestalt Test - Koppitz System & 8 & 1.15 \\
\hline Human Figure Drawing (DFH- Koppitz) & 7 & 1.01 \\
\hline Agreeableness Scale (EFS) & 7 & 1.01 \\
\hline Lipp's Inventory of Stress Symptoms for Adults (ISSL) & 7 & 1.01 \\
\hline Personality Factorial Inventory (IFP) & 7 & 1.01 \\
\hline Rorschach Method Comprehensive System & 7 & 1.01 \\
\hline Myokinetic Psychodiagnosis (PMK) & 7 & 1.01 \\
\hline Non-verbal Intelligence Test (R-1) & 7 & 1.01 \\
\hline Torrance Tests of Creative Thinking (TTCT) & 6 & 0.86 \\
\hline Children Stress Scale (ESI) & 6 & 0.86 \\
\hline Hospital Anxiety and Depression Scale (HADS) & 6 & 0.86 \\
\hline Inventory of Perception of Familiar Support (IPSF) & 6 & 0.86 \\
\hline Performance School Test (TDE) & 6 & 0.86 \\
\hline Berufsbilder Test (BBT-Br) & 6 & 0.86 \\
\hline Pictorial Recognition Memory Test (TEPIC-M) & 6 & 0.86 \\
\hline Human Figure Drawing (DFH - III) - Wechsler & 5 & 0.72 \\
\hline Scale of Evaluation of Difficulty in Learning to Write (ADAPE) & 5 & 0.72 \\
\hline Depression Scale (EDEP) & 5 & 0.72 \\
\hline Scale of Vulnerability to Work Stress (EVENT) & 5 & 0.72 \\
\hline Neuroticism Factorial Scale (EFN) & 5 & 0.72 \\
\hline State-Trait Anxiety Inventory (IDATE) & 5 & 0.72 \\
\hline Raven`s Coloured Progressive Matrices - General Scale & 5 & 0.72 \\
\hline Self-Reporting Questionnaire (SRQ-20) & 5 & 0.72 \\
\hline Wisconsin Card Sorting Test (WCST) & 5 & 0.72 \\
\hline Bender Visual-Motor Gestalt Test - Other systems & 4 & 0.57 \\
\hline Human Figure Drawing (DFH- Sisto) & 4 & 0.57 \\
\hline Center for Epidemiologic Studies Depression Scale (CES-D) & 4 & 0.57 \\
\hline Scale of Self -Efficacy for Occupational Activities (EAAOc) & 4 & 0.57 \\
\hline State-Trait Anxiety Inventory for Children (IDATE-C) & 4 & 0.57 \\
\hline Iowa Gambling Test (IGT) & 4 & 0.57 \\
\hline Goldbergs General Health Questionnaire (QSG) - Pasquali & 4 & 0.57 \\
\hline House, Tree, Person Test (HTP) & 4 & 0.57 \\
\hline Children's Apperception Test Using Animal Figures (CAT-A) & 4 & 0.57 \\
\hline Concentrated Attention Test (TEACO-FF) & 4 & 0.57 \\
\hline Wartegg Test (WZT) & 4 & 0.57 \\
\hline
\end{tabular}

Note. It is important to note that the DSM-IV Clinical Structured Interview, a tool used in the psychiatric diagnosis, was identified in 17 (2.44\%) of the researches in Psychological Assessment that were in the study. ${ }^{*}$ The acronyms are corresponding to the version presented in Brazilian research, or original name, when instrument developed in the country. 
systems and study versions, so one should know that, were this aspect disregarded, certain instruments would show higher numbers. For instance, it would present Bender with $N=22$, DFH with $N=19$, Raven with $N$ $=18$, WISC with $N=15$ and Rorschach with $N=11$.

\section{Discussion}

Items that constitute in the analysis are the disclosures of scientific articles by database, periodic and year of publication. In this respect it is important to describe that the registration of materials for the years 2011 and 2012 was only confirmed in February 2014, since it was found that a significant number of material was still unavailable to the databases at the time of the initial search in March 2013. This finding makes us recommend the setting of some reasonable time to perform analysis of the scientific production of a given year, in bibliometric or metascientific analysis, when based on search results in databases. Moreover, this late indexing of researches extends the time of invisibility of such research to the scientific community, which is aggravated due to the previously elapsed time between the submission and publication of research in journals.

UNB, USP, PUC-Campinas, UFRGS, USF, and PUC-Minas, as mentioned by Chiodi and Wechsler (2008), are among the institutions that, in the 1980s and 1990s, were of great importance to the area of Psychological Assessment for the activation of their research laboratories in measuring and development of psychological instruments. As noted, these institutions are among those which in the decade 2003-2012 showed some of the greatest scientific production volumes in psychological assessment in the country.

Five of the ten most widely disseminated journals of the theme are produced by universities, which are also among the largest productions in the area (USF, USP, UFRGS, PUC-Campinas, and Mackenzie). The receptivity of the productions in the area in these journals, for some of them have emphasis on the subject, contributes to the maintenance of their predominance in the dissemination of Psychological Assessment. We highlight that in addition to psychology journals, research in Psychological Assessment were also present in journals from other areas, such as psychiatry; neurology; special education; public health; speech therapy and nursing.

Like the results from other studies (Joly et al., 2010; Barroso, 2010; Cunha et al., 2009; Suehiro, et al., 2009; Suehiro et al., 2007; Suehiro \& Rueda, 2009), research shows there is a clear disproportionality in the geographical distribution of scientific production of Psychology in Brazil. It should be noted that concentrations in Regions such as Southeast and South, are related to a number of features of these places, such as its high concentration of graduate and research institutions, their accumulation of skilled human capital, the maintaining of effective interinstitutional relations, the presence of technological resources, and the institutional focus on scientific production.

As noted, researchers from the Southeast and South are present in $90.94 \%$ of identified articles, while researchers or institutions in the North and Midwest develop few authorships. Of course, one should not fail to consider the small number of postgraduate courses in Psychology in these locations, but the deficit of research focused or tangential to Psychological Assessment in such regions reveals its low development in the area and certainly sets us the challenge of questioning and thorough discussion about the implications of socio-cultural specificities in Psychological Assessment. For these analysis, we point out that investment is needed in areas of little production, to expand and advance the research and training in the area.

Since 2006 the CFP has established thematic years, which focus on the discussion of issues of great importance to the profession. In the years 2011 and 2012, this proposition was directed to the Psychological Assessment, in order to map the requirements for qualification in the area and discuss the adequacy of tools to ethical standards of the profession and the contexts of their use. It is observed that for the Psychological Assessment, the beginning of the theme year coincides with the period of deceleration of scientific literature published in the area. Given the increase in the volume of publications in the following year, it can be assumed that the event has generated effect on the subject's visibility, as shown in Figure 3. Not so much in relation to the studies for the development of instruments, but in the totality of the studies in the area.

The analysis of the production of this decade of Psychological Assessment demonstrates a predominantly busy research scenario with empirical work, development of tools, and use of them for the study of psychological phenomena and processes. The historical past of stagnation of studies in Psychological Assessment, which culminated in the absence of development, adaptation and also standardization of instruments, in the 1970s to mid-1990s, may be a factor leading to understand this scenario. 
Amid the yearning for Psychological Assessment in new areas in Brazil, there is the requirement of a quest for overcoming the instrumental and training needs which were created in our history. With Resolution No. 25/2001 (CFP, 2001), the CFP has a clear requirement of publications studies and psychometric review for the use of psychological tests, which can be seen as the background for the national focus on empirical publications like this. Out of 553 empirical studies, we identified that $54.79 \%$ were solely focused on the presentation of data on psychometric instruments. It appears that the universe of 303 publications, which had the purpose of researching the development of psychological instruments, only two consisted of a presentation of the theoretical study on it.

In analysis of all publications, we see a lack of technical and critical-reflective work, committed to the organization and interpretation of the data gathered, by the combination of different tools, techniques and methods in the evaluation process. Anache (2011) points out that the validity of psychological analysis depends on the professional competence to obtain and work with data that was obtained through the evaluation process and, in this regard, it is required to integrate and contextualize information built by different means available to the professional. Noronha et al. (2002) also reiterate that it is such competence that ensures proper interpretation of the results of an evaluation process.

Anyway, either for the techniques, instruments or methods, we confirm that the professional should make use of various research strategies to compose relevant information about a particular object of study. These different data obtained in the process would complement only as a consequence of analysis. However, while examining the publications of empirical study, it is observed that the data integration activity for the interpretation of psychological phenomena and processes is not the highlight. Though it is observed, that the selection of individual data does not show the multifaceted dynamics of the psyche. This finding calls into question the ability to relate the different expressions of information that would corroborate the understanding of the psychological dynamics and the phenomenon under study.

The consensus on the technical limits of psychological instruments, an attitude of understanding them as auxiliary resources in a professional practice is required. This means that their application should be complementary or a support to an analysis based on a set of other information built during the evaluation process. However, it is observed in the research that the instruments are still the primary, if not the only, source of information on the investigating objects. Moreover, they are not explored beyond their results, as inducers of behavior and of psychological dimension, which could provide additional information that corroborate or complement the analyzed data.

This survey found a higher rate in the developed work applied to contexts of clinical psychology, health psychology, and school and educational psychology, which are areas of professional work that make up the history of Psychology and Psychological Assessment. It is worth mentioning that the health psychology and clinical psychology, which between them share many professional nuances, stand out. In addition to the historical constitution in psychology training, one must consider the strong identification of psychology as health area, recognized by Resolution No. 218 of the National Health Council, March 1997 (Brazil, 1997), which tends to drive academic and career interest to this area.

As is pointed out in the Psychological Assessment thematic year's report (CFP 2013) and has been pointed out by some authors (Anache \& Corrêa, 2010; Anache \& Reppold, 2010), it is imperative to expand the spaces for discussion and development of this activity in the various contexts in which the psychologist works. For instance, to support the proposition of a debate on the criminological examination, which was raised in the Closing Seminar of the Psychological Assessment thematic year (CFP, 2013), it is noted that this study identified only four studies about this. As noted by Anastasi \& Urbina (2000) and is an Anache \& Reppold argument (2010), one must ascertain the validity of psychological techniques and instruments in the specificity of these contexts, for the match between demand and methodology should be analyzed.

\section{Final Considerations}

On the metascientific model (Witter, 1999), the analytical work of the Brazilian production made it possible to gather relevant information about the decade 2003 to 2012, of the Psychological Assessment area. Data could be produced on the national scenery characterization, in the period following the establishment of the Advisory Committee on Psychological Assessment, which demarcates greater participation of the Federal Council of Psychology in the scientific and professional development of the area. 
It is important to take some precautions when interpreting the scope of the results, due to relative limitations on the methodology applied in the study. We emphasize that: a) the corpus of analysis is conditioned to the search method used and one should, therefore, consider that the result of the query to databases by descriptors psychological assessment and psychological tests, in absolute values, caution should be exercised, since it is not supposed to have covered all materials on the subject; b) the analysis investigations are directed into identifying regularities / irregularities between items and categories of research, which could produce other relevant information; c) on the analysis of the context and theme of the production, it was considered the affinity of the object and study approach with the fields of psychology, since there is a prevalent lack of context of the specification to which certain instruments apply.

Adding that to other studies promoted to evaluate the area and their production, it is expected that this research will contribute to new possibilities of advancement in the development of psychology on the national scene. It should be considered that it is of common interest that investments in the development of Psychological Assessment are expanded and that the technical and scientific capabilities of its implementation are analyzed, whether or not proceeded with the use of psychological tests.

\section{References}

Alchieri, J. C., \& Cruz, R. M. (2003). Avaliação psicológica: Conceito, métodos e instrumentos. São Paulo: Casa do Psicólogo.

Anache, A. A. (2011). Notas introdutórias sobre os critérios de validação da avaliação psicológica na perspectiva dos Direitos Humanos. In Federal Conselho Federal de Psicologia, Ano da Avaliação Psicológica: Textos geradores (pp. 17-20). Brasília: CFP.

Anache, A. A., \& Corrêa, F. B. (2010). As políticas do conselho federal de psicologia para a avaliação psicológica. In Conselho Federal de Psicologia, Avaliação Psicológica: Diretrizes na Regulamentação da Profissão (pp. 19-30). Brasília: CFP.

Anache, A. A., \& Reppold, C. T. (2010). Avaliação Psicológica: Implicações éticas. In Conselho Federal de Psicologia, Avaliação Psicológica: Diretrizes na
Regulamentação da Profissão (pp. 57-86). Brasília: CFP.

Anastasi, A., \& Urbina, S. (2000). Testagem psicológica. Porto Alegre: Artes Médicas.

Barroso, S. M. (2010). Avaliação psicológica: Análise das publicações disponíveis na SciELO e BVS-Psi. Fractal: Revista de Psicologia, 22(1), 141-154. doi: 10.1590/S1984-02922010000100011

Brasil. (1997). Resolution n 218 of March 6, 1997. Brasília: Conselho Nacional de Saúde.

Chiodi, M. G., \& Wechsler, S. M. (2008). Avaliação psicológica: Contribuições brasileiras. Boletim - Academia Paulista de Psicologia, 28(2), 197-210. Retrieved from http://pepsic.bvsalud.org/scielo.php?pid=S1415-711X2008000200008\&script=sci_arttext

Conselho Federal de Psicologia. (2000). Resolução CFP $n^{0}$ 012/2000. Brasília: CFP. Retrieved from http:/ / site.cfp.org.br/wp-content/uploads/2000/12/resolucao2000_12.pdf

Conselho Federal de Psicologia. (2001). Resolution CFP $n^{\circ}$ 25/2001. Brasília: CFP. Retrieved from http:// site.cfp.org.br/wp-content/uploads/2003/06/resolucao2003_7.pdf

Conselho Federal de Psicologia. (2002a). Resolution CFP $n^{0}$ 001/2002. Brasília: CFP. Retrieved from http:/ / site.cfp.org.br/wp-content/uploads/2002/04/resolucao2002_1.pdf

Conselho Federal de Psicologia. (2002b). Resolution CFP $n^{\circ}$ 016/2002. Brasília: CFP. Retrieved from http:/ / site.cfp.org.br/wp-content/uploads/2002/12/resolucao2002_16.PDF

Conselho Federal de Psicologia. (2003a). Resolution CFP $n^{o} 002 / 2003$. Jornal do CFP, 18(75), Caderno Especial, 1-8.

Conselho Federal de Psicologia. (2003b). Resolution CFP $n^{\circ}$ 007/2003. Brasília: CFP. Retrieved from http:// site.cfp.org.br/wp-content/uploads/2003/06/resolucao2003_7.pdf

Conselho Federal de Psicologia. (2004). Suplemento Especial: Testes psicologicos. Brasília: CFP.

Conselho Federal de Psicologia. (2013). Relatório do ano temático da avaliação psicológica 2011/2012. Brasília: CFP. Retrieved from http://site. cfp.org.br/wp-content/uploads/2013/03/ FOLDER_ANO_TEMATICO_CFP_V4.pdf 
Conselho Nacional de Desenvolvimento Científico e Tecnológico. (n.d.). Indicadores de pesquisa. Indicadores das grandes áreas do conbecimento (comparações entre a grande área e o total). Brasília: CNPq. Retrieved from http://www.cnpq.br/web/guest/indicadores1

Cunha, N. B., Suehiro, A. C. B., Oliveira, E. Z., Pacanaro, S. V., \& Santos, A. A. A. (2009). Produção científica da avaliação da leitura no contexto escolar. Psico, Porto Alegre, 40(1), 17-23. Retrieved from http://revistaseletronicas.pucrs.br/ojs/index.php/revistapsico/article/view/2046/4137

International Testing Commission (2003). Diretrizes para o uso de testes: International Testing Commission - Versão em português (S. M. Wechsler, Trad.). Retrieved from http://www.ibapnet.org.br/docs/ DiretrizesITC.PDF

Joly, M. C. R. A., Berberian, A. A., Andrade, R. G., \& Teixeira, T. C. (2010). Análise de teses e dissertações em avaliação psicológica disponíveis na BVS-PSI Brasil. Psicologia: Ciência e Profissão, 30(1), 174-187. doi: 10.1590/S1414-98932010000100013

Law no 4.119, of August 27, 1962. It provides for the training courses in Psychology and regulates the profession of Psychologist. Brasília, DF: Presidency of the Republic.

Marconi, M. A., \& Lakatos, E. M. (2010). Fundamentos de metodologia científica. 7. Ed. São Paulo: Atlas.

Noronha, A. P. P., \& Alchieri, J. C. (2005)Reflexões sobre os instrumentos de Avaliação Psicológica. In R. Primi (Ed.). Temas em avaliação psicológica (pp. 19-36). Casa do Psicólogo.

Noronha, A. P. P., Ziviani, C., Hutz, C. S., Bandeira, D.; Custódio, E. M., ... Domingues, S. (2002). In defesa da avaliação psicológica. Avaliação
Psicológica, 1(2), 173-174. Retrieved from http:// pepsic.bvsalud.org/scielo.php?pid $=$ S1677-04712002000200010\&script=sci_arttext

Noronha, A. P. P., \& Reppold, C. T. (2010). Considerações sobre a avaliação Psicológica no Brasil. Psicologia: Ciência e Profissão, 30(n.spe), 192-201. doi: 10.1590/S1414-98932010000500009

Pasquali, L., \& Alchieri, J. C. (2001). Os testes psicológicos no Brasil. In L. Pasquali (Org.). Técnicas de Exame Psicológico (pp. 195-221). São Paulo: Casa do Psicólogo.

Suehiro, A. C. B., \& Rueda, F. J. M. (2009). Revista Avaliação Psicológica: Um estudo da produção científica de 2002 a 2007. Avaliação Psicológica, 8(1), 131-139. Retrieved from http://pepsic.bvsalud.org/scielo.php?script=sci_arttext\&pid $=$ S1677-04712009000100012

Suehiro, A. C. B., Cunha, N. B., \& Santos, A. A. A. (2007). Avaliação da escrita no contexto escolar entre 1996 e 2005. Psic - Revista de Psicologia da Vetor Editora, 8(1), 61-70. Retrieved from http://pepsic. bvsalud.org/pdf/psic/v8n1/v8n1a08.pdf

Suehiro, A. C. B., Rueda, F. J. M., Oliveira, E. Z., \& Pacanaro, S. V. (2009). Avaliação do autoconceito no contexto escolar: análise das publicações em periódicos brasileiros. Psicologia: Ciência e Profissão, 29(1), 18-29. doi: 10.1590/S1414-98932009000100003

Witter, G. P. (1999). Metaciência e leitura. In G. P. Witter (Org.), Leitura: textos e pesquisas (pp. 13-22). Campinas: Alínea.

Recebido: 26/11/2014

Primeira reformulação: 04/03/2015

Aprovado: 24/03/2015 
Sobre os autores:

Ariállisson Monteiro dos Santos é graduado em Psicologia pela Universidade Federal de Mato Grosso do Sul (UFMS) e, atualmente, aluno do curso de Especialização em Avaliação Psicológica do IPOG e do curso de mestrado em Psicologia da UFMS.

E-mail: ariallisson.contato@hotmail.com

Alexandra Ayach Anache é professora titular da UFMS nos cursos de graduação e mestrado em Psicologia, e do mestrado e doutorado em Educação. Possui doutorado em Psicologia Escolar e do Desenvolvimento Humano, pela Universidade de São Paulo (USP), e pós-doutorado em Educação pela Universidade de Brasília (UnB).

E-mail: alexandra.anache@gmail.com

Ronilce Cavichioli de Santana é graduada em Psicologia pela UFMS, com mestrado em Psicologia também pela UFMS.

E-mail: ronilcecs@gmail.com

Contato com os autores:

Ariállisson Monteiro dos Santos

E-mail: ariallisson.contato@hotmail.com

Universidade Federal de Mato Grosso do Sul, Centro de Ciências Humanas e Sociais Cidade Universitária s/nº , Caixa-postal: 549; Campo Grande/MS - Brasil

CEP: 79070-900

Psico-USF, Bragança Paulista, v. 20, n. 3, p. 547-559, set./ dez. 2015 
